\title{
Women in Top Management and Corporate Share Price: The Mediating Role of Management Learning
}

\author{
Felicity K. Mathye
}

University of Limpopo, South Africa

felicity.mathye@ul.ac.za

Collins C. Ngwakwe

University of Limpopo, South Africa

collins.ngwakwe@ul.ac.za

The objective of this paper is to evaluate the relationship between the number of females in corporate top management and share value. Given the inconsistencies in previous research, this paper contributes a new model to existing literature by mediating the number of women in top management with the 'management learning' variable, which is absent in previous research models. The paper applied a panel data regression approach. Findings from the first analysis (without management learning) indicate a positive relationship (though not significant). Findings from the second analysis (with management learning into the model) show that women in top management are positively and significantly related to share value. The paper concludes that the inclusion and supporting of women in top management through management learning can create a competitive value for the organisation. The paper recommends extension of this new model in future research with more time series and more cross sectional units.

Key Words: share price, gender equity, women in top management, corporate governance, market value, management learning

JEL Classification: G1, G11, G12, G13

https://doi.org/10.26493/1854-6935.18.111-126

\section{Introduction}

Within the twenty first century, businesses around the world have grown in profit accumulation occasioned by improvements in manufacturing technology and computerised business processes. Despite growing profits and multinational expansions, businesses are confronted with a contemporary issue of ensuring that businesses' processes align with sustainable development ideals. One of the sustainable and responsible business expectations is the inclusion of women in corporate top-level management to enhance gender equity. 
Accordingly, the interconnection between sustainable development and globalisation of business has witnessed an incessant growth in the campaign for gender equality (Johnsson-Latham 2007). This has become important as part of worldwide effort for effacing gender and other forms of discrimination in business and organisational management (Kates, Parris, and Leiserowitz 2005; Grosser 2009; Roberts 2015). It is believed that global human wellbeing and economic development will be better if there is a pragmatic transition to gender inclusiveness in all spheres of human activity including corporate management (Kabeer 2016). Within the corporate sector, women have been found to occupy a smaller number of seats in top management positions than men (Johnsson-Latham 2007). This phenomenon is anti-developmental given huge talents that are endowed in women, which are suppressed by relegating women's leadership and decision making opportunities.

This research problem is inclined on continuous exclusion of women in top management, particularly in South Africa. Despite global advocacy for transition to gender equity, as of 2018, research shows that only one woman CEO appear in the top listed companies in South Africa (Mabuza 2018). Globally, as of May 2018, only $4.8 \%$ women are CEOS in the global Fortune 500 companies (Mejia 2018). Why gender discrimination against women continues in the work place is seen simply as a matter of archaic perception and stereotype with the erroneous belief that masculinity is better associated with leadership achievement (Heeraman 2016).

It is unfortunate that some organisations fail to appreciate the myriad of talent endowed in women, which are absent in entities dominated by men. For instance, research based on practical evidence shows how women are endowed with talent and wisdom to navigate and balance the world of corporate career with a successful family responsibility (Stromberg 2017). However, despite the excellent talents in women, there is a persistence of reservations in some quarters that inclusion of women in leadership might affect firm performance negatively (Shrader, Blackburn, and Iles 1997). Yet other researchers dispute the acclaimed negative effect of women leadership on firm performance and suggest that women leadership might rather improve firm performance (Carter, Simkins, and Simpson 2003; Post and Byron 2015; Glass, Cook, and Ingersoll 2016). These divergent views connote ambiguity and inconsistency in current research findings about this relationship (Shrader, Blackburn, and Iles 1997). Such inconsistencies in opinion may arise either from different methods of research and from cultural settings given existence of some 
cultural stereotypes against women (Post and Byron 2015). Accordingly, academics and scholars have a role to play in helping businesses to appreciate the urgent need to accommodate and capacitate women in business leadership positions. One avenue to play this gender advocacy role is through research that identifies relationship between women leaders and business performance; this research contributes to this role.

Research on managers' performance management have highlighted the important role of management learning in enhancing performance (Den, Boselie, and Paauwe 2004; Hayes, Rose-Quirie, and Allinson 2000). However, research on women in management and firm performance has been silent about the mediating role of management learning with women in top management on share price performance. Based on this gap in research, this paper adopts a slightly different model from previous research and makes a contribution to previous studies on women in management and firm performance by including 'management learning' variable in the regression model. Therefore, the objective of this paper is to evaluate the relationship between women in top management and share price performance before and after mediating the regression model with management learning. Hence the research question is whether a relationship exists between women in top management and share price performance when mediated by management learning.

The paper is organised in four main sections. After this introductory section, the following section presents the theoretical background and a review of the related literature. This is followed by the method and results section. Thereafter, the final section presents the conclusion.

\section{Theoretical Background: The Resource Based Theory and Women in Management}

The main trust of resource based theory is that organisations, which possess strategic resources will use such resource to develop a unique competitive advantage to be ahead of its competitors (Nason and Wiklund 2018). This view believes that every organisation is endowed with a bunch of unique resources that makes them unique and competitive amongst organisations (Conner and Prahalad 1996). Hence, the organisation brings together a diverse genre of resources (Barnat 2014). Strategic management experts argue that organisations should first look inwards to see the wealth of resources that lie embedded within the company and such should be developed and utilised to a fullest extent before looking outwards (Dollinger 1999). In Barnat (2014), human resource is placed first 
in the list of organisational resources, which thus indicates the vital importance of human resource in the organisation. Other resources of the firm then follow, which are the tools used by human resource to achieve the goal of the firm, these include finance, information and physical resources. These resources must be managed efficiently and effectively by an organisation manager using the four pillars of management, which are planning, organising, leading and controlling (Samson, Donnet, and Daft 2018). The human resources of the organisation are endowed with knowledge resource, which has to be tapped by managers to achieve the goal of management. The management of this knowledge is an essential part of innovation management (Roblek et al. 2014). Accordingly, the more sophisticated the pool of managers, the more the profit goal of the firm is achievable (Kavcic et al. 2015). The promotion of gender equity in the organisational management ladder helps to infuse management sophistication needed to achieve organisation goals (Subrahmanian 2004). This is because talented management is gender blind. The talent is endowed by nature and can be found in the male or female gender. This is also how diverse human resource talents are distributed equitably amongst different genders such that when gender equity is embraced in the organisation, this gives way for a better pool of talented managers with diverse characteristics to fortify the resources of the organisation and improve its competiveness (Koyuncu, Burke, and Fiksenbaum 2006). Aside from other acclaimed unique managerial talents in women mangers, research has highlighted that women managers perform outstandingly in international settings, and women managers possess appreciable interpersonal skills that often are not very common in male managers (Jelinek and Adler 1988). An empirical research confirm that women managers appear to be more collaborative and transformative (Rosener 2011), this is an important managerial leadership style needed in the transition to the 4th industrial revolution. Collaboration and synergy of smart ideas is one of the desired management qualities needed in the smart industrial age, such ideas as possessed by humans irrespective of gender, race or colour, hence the development and usage of such resources do not require discrimination of any type, hence the resource synergy theory, which highlights complementarity of skill and knowledge to achieve corporate goals (Zhu 2014).

The resource based theory is thus fundamental in this research, reason being that organisations with strategic resource apply this to create competitive advantage over competitors. Contrary to some discrimina- 
tion against women leaders, empirical research has found that women are strategic resource to the organisation, because women managers possess unique skills that improve overall organisational value (Zhu 2014). But strategic resource in women can be utilised best when organisations take a bold equity step and increase the number of women managers in management positions because it is contended that when more women are involved in management, this gives way to bolstering of diverse resource synergy in the organisation (Zhu 2014). A low number of women managers in the organisation may dampen their morale and overall resource capacity given their perception of inequality in the organisation. However, if the organisation embraces the unique potential in women leaders despite their small representation, such organisations will unleash the best out of women managers and be able to see the strategic and competitive resource inherent in women managers (Zhu 2014).

\section{Literature Review}

Human capital capabilities are seen in many researches as the core behind innovative corporate economic and unique competitive growth opportunities (Nason and Wiklund 2018). This is because human capital constitutes one of the salient invaluable corporate resource (which is knowledge). Current research about the value of human capital and firm performance has advanced toward gender diversity for enhanced value creation through amalgamation of capabilities implicit in different genders (Nason and Wiklund 2018). Such value accruable from merging of different genders cannot be achievable by discriminating against women as corporate leaders, because such discrimination limits versatility and synergy of resources derivable from implicit talent endowed in different genders. This is why the resource based theory regards firms as possessing distinctive resources, which is pivotal for service and product innovations (Nason and Wiklund 2018; Barney, Ketchen, and Wright 2011; Barney 1991). Therefore, corporate internal resources such as human resources are a vital tool for improvement of overall firm performance if human resource is properly mixed (Hitt, Carnes, and Xu 2016). Accordingly, women leaders in the corporate world have been empirically proven to contribute to the overall resource wealth of companies through their unique resource skills (Terjesen, Couto, and Francisco 2016). There should be no justification for discriminating against women managers because some empirical research have found that women leaders possess managerial psychology traits on par with their male counterparts and in some cases, women 
managers are found to outperform men in managerial competences and skills (Linde et al. 2013).

Hence, given the bourgeoning research on firms' human resources, many scholars have thus focused on what researchers regard as the most neglected, which is allowing more women access to the top management position. Therefore, extant research has dwelt on various sub-issues pertaining to women in management and how this impacts corporate competitiveness and performance; some examined women in top management via CEO attributes (Peni 2014) and diverse financial performance implication of women in top management (Cook and Glass 2014; Ming and Hock 2016; Lückerath-Rovers 2013; Christiansen et al. 2016; Liu, Wei, and Xie 2014). These prior researches have come up with diverse methods and findings, which deserve mentioning.

Cook and Glass (2014) find a negative relationship between corporate performance and women in top management. Ming and Hock (2016) find that the number of women in the director position is what matters for firm performance, for instance, they found no evidence of relationship between females in director positions and financial value, but that a relationship becomes noticeable only when more than fifteen women are appointed to the board. The reason is that men's dominance beclouds the voice of one or few women, hence the more women there are in top management the better their impact can be felt since they support each other in solidarity to push women's strategic views to be heard and implemented (Mavin 2008).

Some other research studies on how female managers contribute to the financial growth of the firm have found that the presence of women in the companies' board of directors facilitates the financial value of the firm better than companies that exclude women from their boards (LückerathRovers 2013; Peni 2014). For instance, higher female gender mix in top management of firms in Europe were found to be correlated with better return on assets (Christiansen et al. 2016). A related study in China found that inclusion of more women on the corporate board contributes to better financial success of Chinese firms, but that this performance is more pronounced for females in executive positions than independent positions (Liu, Wei, and Xie 2014). Research has also found that aside from direct relationship between women in the board on firm performance, there are also indirect benefits, for instance, it has been found that women directly increase the value of sales turnover, asset returns and ethical responsibility and that these in turn have indirect positive effects on 
firm share value in the market (Isidro and Sobral 2015). Another research applied regression and event study to examine the long and short-run implication of women directors on corporate boards in Spain. Results indicate that when females are appointed to the corporate board the stock market price improves positively as participants have confidence on the performance of women directors (Campbell and Vera 2010).

This research adds to the previous existing research in a unique way; none of the previous research have integrated management learning into the model equation about role of women in top management on firm performance. The following section provides details of the method used and the findings.

\section{Method and Results}

This research analysis utilised a quantitative method because the data that were used are numerical in nature, and this is amenable to the positivist paradigm approach. Hence, this research applied the positivist paradigm wherein a relationship was sought between two independent variables, which are number of women in companies' top management, number of women with management learning and one dependent variable, which is the share price of companies. Experts believe that a positivist paradigm is used to discover the relationships amongst two or more variables in an empirical analysis (Antwi and Hamza 2015).

The research data were collected through a secondary data process from the financial statements of selected companies from the FTSE/JSE Responsible Investment Index (RI) for the period 2010/2011-2014/2015 financial years. Hence the population of study were the entire 30 top companies listed in the FTSE/JSE RI companies. Applying a purposive sampling approach, 25 companies (that had complete data on the variables of study) were selected from the $30 \mathrm{FTSE} / \mathrm{JSE}$ Responsible Investment Index. Purposive sampling is suitable when the researcher applies judgement regarding what to sample and the characteristics that best serve the purpose of the research (Barratt, Ferris, and Lenton 2015).

The data collected over the five years' period from the 25 sample of companies were arranged according to the panel data approach. Since the analysis involved data collected from different cross section units over different time series, the panel data regression became a suitable data analysis approach for this study (Hsiao 2014; Arellano 2003).

Therefore, research data were analysed using the two regression models as follows. 
TABLE 1 Regression Result on the Relationship between Number of Women in Top Management and Share Price: Model 1

\begin{tabular}{lrccr}
\hline Item & Coefficient & Std. Error & $t$-ratio & $p$-value \\
\hline const & 306.011 & 50.6996 & 6.0358 & $<0.00001^{* * *}$ \\
W IN T M & 26.7885 & 15.0103 & 1.7847 & 0.1576 \\
\hline$R^{2}$ & 0.406 & Observations & 150 \\
Adjusted $R^{2}$ & 0.369 & Cross-sectional units & 25 \\
$F(25,124)$ & 9.914 & Time-series length & 6 \\
$P$-value $(F)$ & 0.477 & Dependent variable & SharePr \\
Schwarz criterion & 2070 & & \\
Rho & 0.191 & & \\
Akaike criterion & 1992 & & \\
Hannan-Quinn & 2023 & & \\
Durbin-Watson & 2.95 & & \\
\hline
\end{tabular}

Model 1 (without management learning)

$$
\gamma=\beta_{\mathrm{o}}+\beta_{1} \chi_{1}+\varepsilon .
$$

Model 2 (with management learning)

$$
\gamma=\beta_{\mathrm{o}}+\beta_{1} \chi_{1}+\beta_{2} \chi_{2}+\varepsilon
$$

Where $\gamma$ is share price, $\beta_{\mathrm{o}}$ is intercept, $\beta_{1}-\beta_{2}$ are coefficients, $\chi_{1}$ is the number of women in top management, $\chi_{2}$ is the number of women with management education, and $\varepsilon$ is error.

\section{Discussion of Findlings}

This analysis made use of two different models; the first model examined the relationship between the number of women in top management and share price of 25 companies in FTSE/JSE responsible investing companies. Since no previous research has considered the role of management education, the second model contributes a nuance to existing research by considering the moderating role of management learning proxied by the number of women managers holding management education. The comparative examination of the two different models in table 1 with single independent variable (number of women in top management) and table 2 which added a moderating variable (management learning) show different results worthy of noting. A closer view on values of Akaike, HannanQuinn and Schwarz criterion between table 1 and table 2 indicates that 
TABLE 2 Regression Results of Women in Top Management and Share Price (Moderated by Management Learning): Model 2

\begin{tabular}{lrcrr}
\hline Item & Coefficient & Std. Error & $t$-ratio & $p$-value \\
\hline const & 301.386 & 52.4709 & 5.7439 & $<0.00001^{* * *}$ \\
W IN T M & 34.077 & 25.2137 & 1.3515 & $0.03901^{* *}$ \\
MgtLearn & 11.5933 & 32.1619 & 0.3605 & 0.17912 \\
\hline$R^{2}$ & 0.666 & Observations & 150 \\
Adjusted $R^{2}$ & 0.599 & Cross-sectional units & 25 \\
$F(25,124)$ & 65.91 & Time-series length & 6 \\
$P$-value $(F)$ & 0.0041 & Dependent variable & SharePr \\
Schwarz criterion & 1000 & & \\
Rho & 0.720 & & \\
Akaike criterion & 802.0 & & \\
Hannan-Quinn & 970.0 & & \\
Durbin-Watson & 1.862 & & \\
\hline
\end{tabular}

model 2 results in a much lower statistics for Akaike, Hannan-Quinn and Schwarz criterion. Since these three statistics are used to detect a better model, it becomes clear that model 2, which has lower values for Akaike, Hannan-Quinn and Schwarz criterion than model 1 is a preferred model; this is because these statistics are widely used to decide an alternative model that provides a better linear fit (Iida, Miyata, and Shiohama 2018; Davidian and Gallant 1993). Additionally, a comparison of Durbin Watson statistics value in the two models shows which model is autocorrelation free. Model 1 has a Durbin Watson statistics value of more than 2, indicating presence of autocorrelation, but model 2 has a Durbin Watson statistics value of less than 2, which shows absence of autocorrelation, indicating independence of residuals (King 2018). In model two, the correlation test, which is represented by the rank correlation (rho) show a positive value of 0.72 , indicating that more women in top management and more women with management learning do play a positive role on the value of share price. The total significance of model 2 (with two independent variables) is indicated by the $F$-test. The values comprise the $F$-critical value of 65.9 and $P$-value $(F)$ of 0.004 , which is lower than the research alpha value of $5 \%$ (0.05). The low $p$-value of the $F$ indicates that the introduction of management learning in model two makes the model (number of women in top management and management learning) to 
be significantly and positively related to share price; it can be seen that this significance of $p$-value is absent in model 1 , hence the introduction of management learning can play a helpful role in enhancing better performance of women managers in top management. This adds to previous allusions that there is indeed a business value case for women managers (Hoobler et al. 2018).

The analysis and results in table 1 and table 2 were conducted at an alpha $(\alpha)$ of 0.05 . A two stage analysis was therefore conducted, the first stage in table 1 excludes the management learning variable, but the second stage analysis in table 2 includes the management learning variable in the regression analysis (see also models 1 and 2). From the results in table 1 , the Now TM (number of women in top management) indicates a $p$-value of 0.15 , which is higher than the research alpha level of 0.05 . This shows that the relationship is not significant. However the $R^{2}$ of $46 \%$ does show that a relationship exists between women in top management and share price (although not significant). Important to note is that the regression coefficient for women in top management shows a positive number of 26.788 , which means that the women in top management is positively related to share price performance. This means that increase in the number of women in top management can increase the value of share price. The second stage analysis introduced management learning variable into the regression model to test the mediating role of management learning, whether management learning might improve the role of women in top management. The result in the second test (table 2) shows that women in top management is positively and significantly related to share value with a $p$-value of 0.039 , which is less than the research alpha of 0.05 . It can also be seen in table 2, that with the introduction of management learning variable, the $R^{2}$ (which is the coefficient of determination) value increased to $66 \%$, indicating a stronger association with the introduction of management learning. This analysis is different from previous research as this is the first introduction of management learning in analysing the role of women in top management on corporate share price performance. It should be noted that other factors, which affect share price were held constant in order to isolate the role of women in top management and these other factors were represented by the error term in the regression model (in model 1 and model 2).

Findings from the foregoing analysis are important in motivating for gender equity in top management. At least from the share price argument, the result implies that allowing women in top management posi- 
tion would not necessarily affect companies' share price negatively, rather there is the potential that the effect of women in top management might have a positive effect on share price value given the positive sign on the regression coefficients in table 1 and table 2 analysis. The result of this research corroborates the findings of Paustian-Underdahl, Walker and Woehr (2014) who found similar results that firms with more women in senior anagement are more profitable and have higher share prices. Similarly, findings from Christiansen et al. (2016) suggest that the stock market has the likelihood to react positively with improved share price on new appointments of women on the corporate board of directors. Other studies have equally opined the positive market value, returns on equity and high payout ratios associated with women on the corporate board (Ahern and Dittmar 2012). However, this result differs from a previous research that found a somewhat negative relationship between women leadership and firm performance such as Cook and Glass (2014); this might be due to methodological differences. The result of this study is limited within the number of years used and within the 25 companies studied. This research therefore serves as a first investigation using this new model with management learning and thus providing an agenda for future research to expand this research using this model. Figure 1 presents a summary framework of the model used in this analysis for theoretical and research application. Drawing from these research findings, the figure framework is that a combination of women in top management and management learning (developing the managerial skill of women through management education) can lead to improved share price. Other factors which can influence share price are represented by the error term and the error term function (for other missing variables) is allowed in statistical research (Plonsky and Ghanbar 2018). This framework can be tested and expanded by future researchers.

\section{Conclusion}

This research explored the relationship between the number of females as top managers and companies' share price by using selected corporates from the F T SE/JSE Responsible Investment Index. This paper was pertinent given existing low number of females in corporate top management in South Africa, hence this research was meant to provide empirical information for company policy makers that there is no share value disadvantage, which may arise by involving female leaders in companies' management. This paper adds to the existing literature to South African 
FIGURE 1

Women in Top

Management Link with

Share Price (Moderated

by Management Learning)

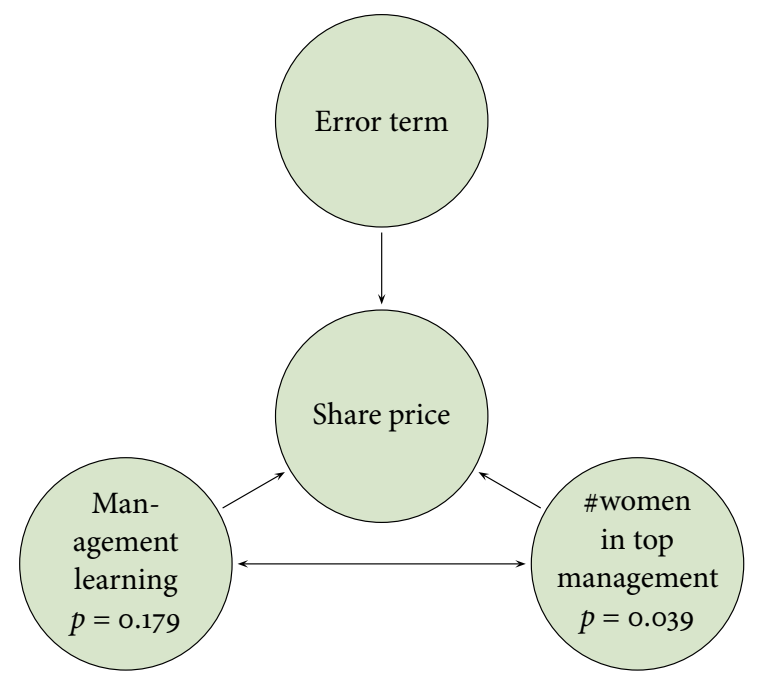

studies on the value accruable from the appointment of women to top management positions, but it has differed slightly from previous research as this research focused only on stock price implication of women on top management and by adding management learning as mediating variable, which has largely not been present in previous women mangers' value analyses. Hence the important contribution of this research is that it adds to existing literature by introducing management learning into the regression model, which is absent in previous research models.

A two stage analysis disclosed two different results; results from the first stage regression analysis indicate a positive relationship between the number of women in top management and corporate share value; but at this stage, the relationship is not significant in the first examination without management learning. The second test introduced management learning into the regression model to visualise the mediating role of management learning. The result in the second test shows that women in top management are positively and significantly related to share value with a $p$-value less than 0.05. This findings suggests that, within the sample of companies used in this research, management learning is an important factor that can enhance the role of women in top management on firm performance. It therefore means that supporting women in top management through management learning can create a competitive value for the organisation, which supports the resource based theory that human resource can produce a competitive advantage for the organisation. This 
new finding makes a practical and theoretical contribution to business and the literature. The practical implication to business is that organisations can enhance their strategic value by not only including more women in top management, but also by capacitating women's managerial skills through management learning. Further, it should extend this new research model by adding more time series and by expanding the number of companies in future research. Given the current low position of women CEOS in South Africa, which stands at about only three percent (Tsako 2017), this paper recommends that the corporate world could contribute to the global transition to gender equity by appointing more women in top management positions such as in the CEO positions. There should be no fear of possibility of financial loss because previous studies and this research have confirmed that the stock market believes in the value potential inherent in women managers.

\section{References}

Ahern, K. R., and A. K. Dittmar. 2012. 'The Changing of the Boards: The Impact on Firm Valuation of Mandated Female Board Representation.' The Quarterly Journal of Economics 127 (1): 137-97.

Antwi, S. K., and K. Hamza. 2015. 'Qualitative and Quantitative Research Paradigms in Business Research: A Philosophical Reflection.' European Journal of Business and Management 7 (3): 217-25.

Arellano, M. 2003. Panel Data Econometrics. Oxford: Oxford University Press.

Barnat, R. 2014. 'Strategic Management: Formulation and Implementation. https://introduction-to-management.24xls.com/en105

Barney, J. 1991. 'Firm Resources and Sustained Competitive Advantage.' Journal of Management 17 (1): 99-120.

Barney, J. B., D. J. Ketchen, and M. Wright. 2011. 'The Future of ResourceBased Theory Revitalization or Decline?' Journal of Management 37 (5): 1299-315.

Barratt, M. J., J. A. Ferris., and S. Lenton. 2015. 'Hidden Populations, Online Purposive Sampling, and External Validity: Taking off the Blindfold.' Field Methods 27 (1): 3-21.

Carter, D. A., B. J. Simkins., and W. G. Simpson. 2003. 'Corporate Governance, Board Diversity, and Firm Value.' Financial Review 38 (1): 33-53.

Campbell, K., and A. M. Vera. 2010. 'Female Board Appointments and Firm Valuation: Short and Long-Term Effects.' Journal of Management \& Governance 14 (1): 37-59.

Christiansen, L., H. Lin., J. Pereira., P. B. Topalova., and R. Turk. 2016. 'Gender Diversity in Senior Positions and Firm Performance: Evidence 
from Europe.' I M F Working Paper 16/50, International Monetay Fund, Washington, DC.

Conner, K., and C. Prahalad. 1996. 'A Resource-Based Theory of the Firm: Knowledge versus Opportunism.' Organisation Science 7 (5): 477-501.

Cook, A., and C. Glass. 2014. 'Women and Top Leadership Positions: Towards an Institutional Analysis.' Gender, Work \& Organization 21 (1): 91-103.

Davidian, M., and A. R. Gallant. 1993. 'The Nonlinear Mixed Effects Model with a smooth Random Effects Density'. Biometrika 8o (3): 475-88.

Den, H. D. N., P. Boselie, and J. Paauwe. 2004. 'Performance Management: A Model and Research Agenda.' Applied Psychology 53 (4): 556-69.

Dollinger, M. J. 1999. Entrepreneurship Strategies and Resources. Upper Saddle River, NJ: Prentice Hall.

Glass, C., A. Cook., and A. R. Ingersoll. 2016. 'Do Women Leaders Promote Sustainability? Analyzing the Effect of Corporate Governance Composition on Environmental Performance.' Business Strategy and the Environment 25 (7): 495-511.

Grosser, K. 2009. 'Corporate Social Responsibility and Gender Equality: Women as Stakeholders and the European Union Sustainability Strategy' Business Ethics: A European Review 18 (3): 290-307.

Hayes, J., A. Rose-Quirie., and C. W. Allinson. 2000. 'Senior Managers' Perceptions of the Competencies They Require for Effective Performance: Implications for Training and Development.' Personnel Review 29 (1): 92-105.

Heeraman, J. 2016. 'Why Are Female ceos Discriminated Against?' The Business Woman, 10 November. https://www.thebusinesswomanmedia .com/why-are-female-ceos-discriminated-against/

Hitt, M. A., C. M. Carnes., and K. Xu. 2016. 'A Current View of Resource Based Theory in Operations Management: A Response to Bromiley and Rau. Journal of Operations Management 41 (10): 107-9.

Hoobler, J. M., C. R. Masterson., S. M. Nkomo., and E. J. Michel. 2018. 'The Business Case for Women Leaders: Meta-Analysis, Research Critique, and Path Forward.' Journal of Management 44 (6): 2473-99.

Hsiao, C. 2014. Analysis of Panel Data. Cambridge: Cambridge University Press.

Iida, M., Y. Miyata, and T. Shiohama. 2018. 'Bootstrap Estimation and Model Selection for Multivariate Normal Mixtures Using Parallel Computing with Graphics Processing Units.' Communications in StatisticsSimulation and Computation 47 (5): 1326-42.

Isidro, H., and M. Sobral. 2015. 'The Effects of Women on Corporate Boards on Firm Value, Financial Performance, and Ethical and Social Compliance.' Journal of Business Ethics 132 (1): 1-19.

Jelinek, M., and N. J. Adler, 1988. 'Women: World-Class Managers for 
Global Competition.' Academy of Management Perspectives 2 (1): 1119.

Johnsson-Latham, G. 2007. 'A Study on Gender Equality as a Prerequisite for Sustainable Development - Report to the Environment Advisory Council'. Universität Bremen. http://www.uft.oekologie.unibremen.de/hartmutkoehler_fuer_studierende/MEC/o9-MEC -reading/gender\%202007\%20EAC\%2orapport_engelska.pdf

Kabeer, N. 2016. 'Gender Equality, Economic Growth, and Women's Agency: The Endless Variety and Monotonous Similarity of Patriarchal Constraints.' Feminist Economics 22 (1): 295-321.

Kates, R. W., T. M. Parris., and A. A. Leiserowitz. 2005. 'What is Sustainable Development? Goals, Indicators, Values, and Practice.' Environment 47 (3): 8-21.

Kavcic, K., M. Meško., Z. M. Štok., and M. Markic. 2015. 'Corporate Policy and the Degree of Management Sophistication in Slovenian Companies.' International Journal of Management and Enterprise Development 14 (1): 70-88.

King, M. L. 2018. Testing for Autocorrelation in Linear Regression Models: A Survey. London: Routledge

Koyuncu, M., R. J. Burke., and L. Fiksenbaum. 2006. 'Work Engagement among Women Managers and Professionals in a Turkish Bank.' Equal Opportunities International 25 (4): 299-310.

Linde, H., R. Alex., F. Van Vrede, W. Havenga, and J. C. Visagie. 2013. 'A Theoretical and Empirical Analysis of Gender Differences within the African Business Environment.' Managing Global Transitions 11 (1): 4160.

Liu, Y., Z. Wei., and F. Xie. 2014. 'Do Women Directors Improve Firm Performance in China?' Journal of Corporate Finance 28:169-84.

Lückerath-Rovers, M. 2013. 'Women on Boards and Firm Performance.' Journal of Management \& Governance 17 (2): 491-509.

Mabuza, E. 2018. 'New Research Shows there has Been Modest Progress in Gender Transformation at Executive Level, but there Is Only One Woman at the Helm of s A's Top 40 Listed Companies.' BusinessDay, 13 August. https://www.businesslive.co.za/bd/business-and-economy/2018o8-13-sas-top-companies-are-still-not-hiring-female-ceos/

Mavin, S. 2008. 'Queen Bees, Wannabees and Afraid to Bees: No More Best Enemies for Women in Management?' British Journal of Management 19 (1): 75-84.

Mejia, Z. 2018. 'Just 24 Female ceos Lead the Companies on the Fortune 500.' Make It, 21 May. https:/www.cnbc.com/2018/05/21/2018sfortune-500-companies-have-just-24-female-ceos.html

Ming, C., and E. L. Hock. 2016. 'Estimating the Nonlinear Effects of Female Directors on Financial Performance: The Case of Malaysian Ini- 
tial Public Offering Companies.' Gender in Management: An International Journal 31 (2): 97-113.

Nason, R. S., and J. Wiklund. 2018. 'An Assessment of Resource-Based Theorizing on Firm Growth and Suggestions for the Future.' Journal of Management 44 (1): 32-60.

Paustian-Underdahl, S. C., L. S. Walker., and D. J. Woehr. 2014. 'Gender and Perceptions of Leadership Effectiveness: A Meta-Analysis of Contextual Moderators.' Journal of Applied Psychology 99 (6): 1129-45.

Peni, E. 2014. 'CEO and Chairperson Characteristics and Firm Performance.' Journal of Management \& Governance 18 (1): 185-205.

Plonsky, L., and H. Ghanbar. 2018. 'Multiple Regression in L2 research: A Methodological Synthesis and Guide to Interpreting $R^{2}$ Values.' The Modern Language Journal 102 (4): 713-31.

Post, C., and K. Byron. 2015. 'Women on Boards and Firm Financial Performance.' Academy of Management Journal 58 (5): 1546-71.

Roberts, A. 2015. 'The Political Economy of Transnational Business Feminism Problematizing The Corporate-Led Gender Equality Agenda.' International Feminist Journal of Politics 17 (2): 209-31.

Roblek, V., M. Meško., M. P. Bach., and A. Bertoncelj. 2014. 'Impact of Knowledge Management on Sustainable Development in the Innovative Economy.' Paper presented at the 2nd International Symposium Systems Thinking for a Sustainable Economy, 23-24 January, Rome.

Rosener, J. B. 2011. Ways Women Lead. Dordrecht: Springer.

Samson, D., T. Donnet, and R. Daft. 2018. Fundamentals of Management. London: Cengage.

Shrader, C. B., V. B. Blackburn., and P. Iles. 1997. 'Women in Management and Firm Financial Value: An Exploratory Study' Journal of Managerial Issues 9 (3): 355-72.

Stromberg, L. 2017. Work Pause Thrive: How to Pause for Parenthood without Killing Your Career. Dallas, T X: BanBella Books.

Subrahmanian, R. 2004. 'Promoting Gender Equality. In Targeting Development, edited by R. Black and H. White, 208-32. London: Routledge.

Terjesen, S., E. B. Couto., and P. M. Francisco. 2016. 'Does the Presence of Independent and Female Director's Impact Firm Performance? A Multi-Country Study of Board Diversity.' Journal of Management \& Governance 20 (3): 447-83.

Tsako, V. 2017 'Promotion of Women in Top Management Positions.' http://ilgm.co.za/Websites/ilgm/files/Content/6187945/Promotion_of _women_in_snr_management_positions_-_Vuyiwe_Tsako.pdf

Zhu, H. 2014. 'Women as Strategic Resource and Organization Performances: A Perspective of Resource Synergy' Phd dissertation, Hong Kong Baptist University. 